\title{
SOME SEMANTIC AND LEXICAL OBSERVATIONS
}

1. I will not repeat grammatical features that I have extensively described in the Introduction to my JNAD. Instead, I will record below some semantic and lexical observations that I have noticed while preparing this volume.

1.1 English lexemes may have several Neo-Aramaic translations, usually loanwords from different languages, or dialects, periods, or with different nuances useful for the culture, or from different, e.g. "arrange" has: ר-ת t-r-s (OA); );


and some with latent or obvious nuances such as "arrange nicely": ז-ז Z-W-q (Ar); ב-ת-ת-r-t-b (Ar).

1.2 "Basket" has nine or ten translations, according to shape, size, material from which it is made, etc.: זמבילא zambila wicker basket (Ar/K < OA); טבק tabaq shallow basket (Ar); כושא kōša loose dress part that can be used as a basket to carry small things (K "lap”); כרארא xarara basket used by porters (Ar ?); מכבה mıkabbe large and heavy basket made of dry thin tree branches, with a lot of holes for ventilation, used to cover food on the roof at evening so it will not be eaten by birds, cats, etc. (Ar); סלשיר sallašir deep basket, carried on the back (KAr); עולבכתא 'ulblkta small (wooden) -, H tevah (תבה) (סלכתא (Ar-K < OS); s.sallikta basket, container (K); קופא qūpa small wicker basket (OA<Ak), cogקרטליתא quțāla (OS/Ar < Gr); cf. OA qarțalita small basket.

1.3 Similarly, there are several words for (types of) "gift" (distinction — not always clear): דיארי diyyari (K < Ar); הדייה hadiye (Ar); יהותא yhōta (OA);



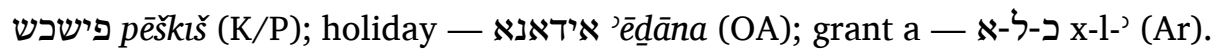

1.4 For types/degrees of "heat": heat כמא ximma (OA); כמימותא (warmth)






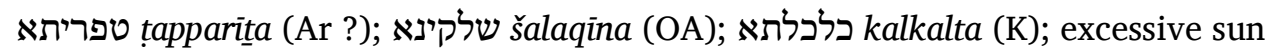



1.5 Complimenting various honest people: honest מורוסת durust (K); מאדק sadıq (Ar); צאלח sāālh (Ar); נקייא niqya (OA); עאדל 'ādıl (Ar); מהימס mhēman (OA);

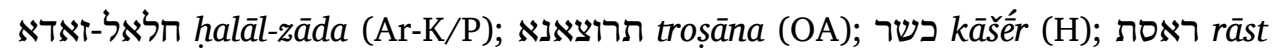

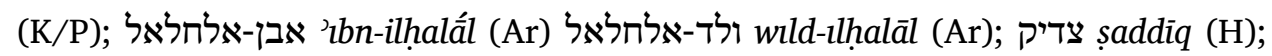
צדאקא șaddāqa (f.).

1.6 Many names and epithets for God, especially in Rabbinical texts, including Judaic loanwords from Hebrew and Islamic from Arabic: אילאהא 'ilāha (OA); (live, eternal) קיים qayēm (H); (exalted) תעם ta'āla (Ar); אואדת עגאבה מallah (Ar); (makerdıt 'ajābe (Ar); (merciful) רחים rahīm (Ar); (merciful and we-ḥannūn (H); (creator) כלאקא xalāqa (Ar); (creator of the world) בורא עולם bōrē 'ōlām (H); (Master of the world) אסתאד עולם 'stā 'ōlām (Ar-H); (God of the universes)

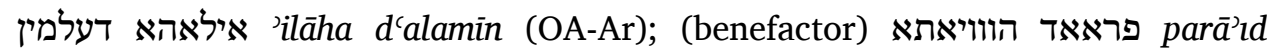
hawuyāta (OA-Ar); (Master of Heavens) רב אל סמאואת rabb ll-samāwāt (Ar);

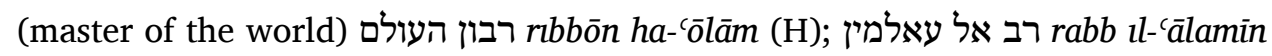

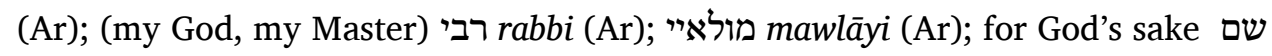

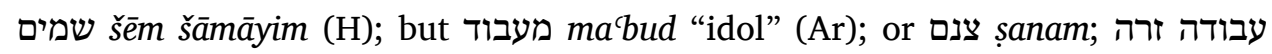
'avōda zāra (H).

\subsection{Types of vessels for preserving liquids, meats:}

jar כדונא baddūna (OA); דיקא biqqa (Ar ?); דנתא danta (OA); כוזא kūza (OA/OS);

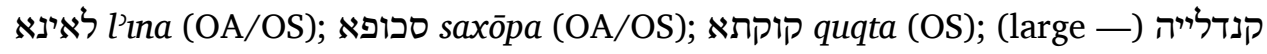
qandaliye ( $\mathrm{K}$ < Ar ?); (large - for carrying water from the river) תלמא (כalma (OS); (hole in the ground holding the bottom of jars) כוזי-דאנכה kūzi-dānke (K).

1.8 midwife (old lady) גדכה jiddıke (K < Ar); (nanny) דאיינה dāyinne (K); (old mother) דאפירכה dāpirke (K); ("receiver, welcomer") מקבלנתא mqablanta (Ar); qabāla (Ar); serve as midwife ק-ב-ל קבאלא q-b-1 (Ar).

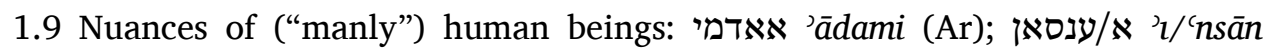
(Ar); בני בשר bani-bašar (Ar); בן אדיה birya (OAdam (H); (humans);

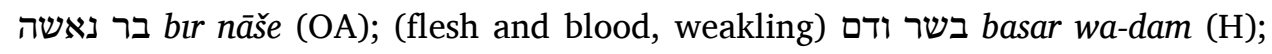
nāša (OA).

1.10 Since many Kurdish Jews worked as loggers, they have different words for different shapes and sizes of wood: ציוה șiwe (OA); דילאנה 'ilāne (OA, Am); many trees דארה-דארה dah̆re-dāre (K); forest, thicket דחלה (K); poplars, cedars 
ספינדארה spundāre (K); box trees רמשאטה rōtăta (Ar); (short log) קורמא qurma (OS < Gr); (thin and long) שקלא; šaqla (one half of split tree).

1.11 Some worked as loggers-rafters: טראחה tarrāḥe (Ar); כלכבאנה kalakvāne (K);


< Akk); raft (similar to kalak) כרכא (karxa (OA ?); large barge made of logs tied to inflated ship-skins עברא 'abra (Ar ?).

1.12 Others worked as guards: guard (n) נטארא națāra (OA); נאטורא nātōora (OA); market night guard חסאסא hasāsa (Ar); watchman קלאויז qaisz (T); road -


working as - נאטורותא nātorūta (OA).

1.13 Various ways of eating: - in general א-כ-ל '-x-1 (OA); - small portions, have a bite נ נ-ק-נ n-q-n-q III (IrAr); — the entire dish, "clean" the plate ג-י-ד-ד y-d (OS/OA); — fruits from the rind or meat off bone ג-ג g-y-ç III (K ?);一 vora-

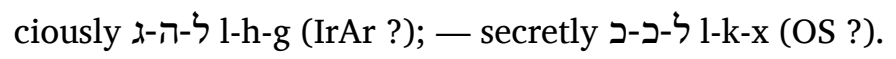

1.14 Various head covers for men and women: scarf: head - בוימא bōyama (T?); thin - הברייא habrīya (IrAr); plain - כפייא kafïya (Ar); silk - כסרוון kasrawan (P?); modern — for men לפאחא liffāha (Ar ?); — made of white linen for covering head and face of children and women נגוֹ מגא niččōka (K); see also rope-ring; cover head with linen scarfe נ-כ-ל ב-č-k II (K); woman wrapped in head scarf חגוֹמה hijūme (Ar).

1.15 Several Kurdish words to indicate local landscape

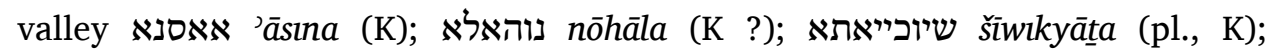
(deep -) כנדאלא kindāla (K); (winding -) גלאלא gali (K).

2. At times, English lexeme has several Neo-Aramaic translations, all or most are loanwords from one language (Arabic, Kurdish, etc.), perhaps suggesting the importance of that term in the life of that culture, e.g.:

2.1 Honor is very important in Kurdish and Arab societies; the origin of the following synonyms is mostly Arabic : גלאלתא jalālıta (Ar); כראמתא karāmita (Ar);

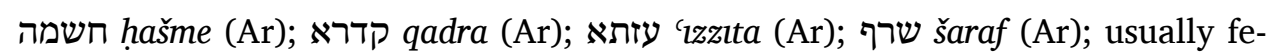
male's ערז 'arz (Ar); However, honoring an elder Jew or a Hakham "Rabbi," a Hebrew word כבוד $k \bar{a} v \bar{o} \underline{d}(\mathrm{H})$ is used.

2.3 Religious and legal terms are all loanwords from Arabic or Hebrew: law

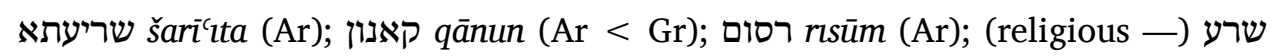


šarc (Ar); (Jewish —) הלכה halāxa (H); (judgment in Jewish -) דין din (H); חלאוק $h \bar{o} q(\mathrm{H})$; Even Jewish terms may appear in Arabic : kosher חלאר halāla; unko-

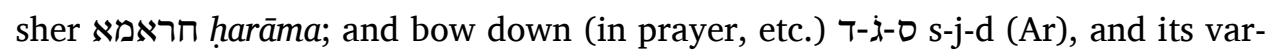

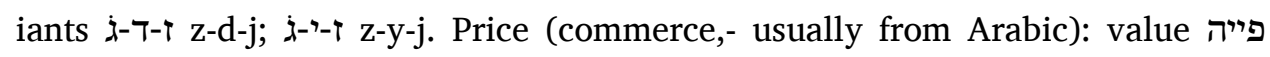
fiye (Ar); קימה qime (Ar); תמן taman (Ar); סען si'ır (Ar); חקא haqqa (Ar).

2.4 Musical instruments are usually in Kurdish, especially wind instruments (used in weddings): flute בלורה bullūre (K); (shrill -) זרנה zơne (K); dūdıkta (T/K); תותכא tūtkka (K, originally "small cucumber"). So are some other popular instruments such as דולא dōla large wedding drum, טמבלכה țmblke, tambourine hand drum played while sitting in small parties.

2.5 Variety of flowers are in Kurdish: wild flowers in general ביבונה bēbūne (K);

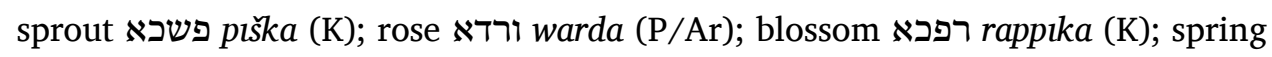
סיסנה glower גולבהר gulčičaka (K); lily, Susanar (K); wild flower סולגיגא (K) sisine (K); all kinds of flowers in a field סוסנ-ו-הלאלת sūsin-u-halālat (K). So are words for "pasture" גרא čara (K); غרואן črwān (K); כויסתאל kwistāne (K); summer - area זוז̄zan (K).

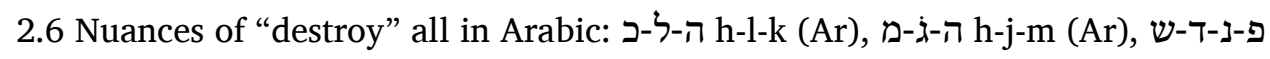



